\title{
The Return of Banishment: Do the New Denationalisation Policies Weaken Citizenship?
}

\author{
Audrey Macklin
}

\begin{abstract}
After decades in exile, banishment is back. Britain resuscitated the practice as part of its counter-terrorism strategy in the wake of the 9/11 and 7/11 terrorist attacks in New York, Washington and London. Canada followed suit with the 2014 Strengthening Canadian Citizenship Act. ${ }^{1}$ As we enter the third decade of the 21st century, assorted legislators in Austria, Australia, Netherlands, and the United States expressed interest in enacting, reviving, or extending citizenship stripping laws. ${ }^{2}$
\end{abstract}

From antiquity to the late 20th century, denationalisation was a tool used by states to rid themselves of political dissidents, convicted criminals and ethnic, religious or racial minorities. The latest target of denationalisation is the convicted terrorist, or the suspected terrorist, or the potential terrorist, or maybe the associate of a terrorist. He is virtually always Muslim and male.

Citizenship-stripping is sometimes defended in the name of strengthening citizenship, but it does precisely the opposite. The defining feature of contemporary legal citizenship is that it is secure. Making legal citizenship contingent on performance demotes citizenship to another category of permanent residence. Citizenship revocation thus weakens citizenship itself. It is an illegitimate form of punishment and it serves no practical purpose.

1 The Canadian legislation was subject to constitutional challenge following completion of this article. It was repealed by a new government in 2017 before the legality of hte legislation was determined and beforeany revocations went into effect.

2 For a more elaborate comparative analysis of recent legislative developments in the United Kingdom, Canada and the US, see Macklin, A. (2014), 'Citizenship Revocation, the Privilege to Have Rights and the Production of the Alien', Queens Law Journal 40 (1): 1-54. 
Denationalisation refers to involuntary loss of citizenship. ${ }^{3}$ Denaturalisation is a subset of denationalisation, and applies selectively to those not born into citizenship via ius soli or ius sanguinis. The most common basis for denaturalisation is fraud or misrepresentation in the acquisition of citizenship. The operative premise is that had the material facts been known at the relevant time, the state would not have conferred citizenship in the first place. Denaturalisation for fraud simply annuls the erroneously conferred citizenship and restores the status quo ante. ${ }^{4}$

My remarks focus exclusively on denationalisation for allegedly disloyal conduct by a citizen, while a citizen. In its present incarnation, citizenship revocation is best understood as a technique for extending the functionality of immigration law in counter-terrorism. Since 2001, states have turned to deportation to resolve threats to national security by displacing the embodied threat to the country of nationality. But deporting one's own citizens is exile, and exile extinguishes a singular right of citizenship, namely the right to enter and to remain. Citizenship revocation circumvents that problem by introducing the two-step exile: first, strip citizenship; second, deport the newly minted alien.

The British Nationality Act authorises the Secretary of State for Home Affairs (Home Secretary) to deprive a person of British citizenship where she 'is satisfied that deprivation is conducive to the public good.' That happens to be the same low and vague standard for depriving a person of permanent resident status (indefinite leave to remain), which provides one illustration of the downgrading of citizenship. In Canada, the executive power to revoke citizenship depends on a criminal conviction for a listed

3 Before the widespread acceptance of dual citizenship, acquisition of a second citizenship or marriage to a foreign man commonly triggered denaturalisation. In a world where states tolerated only one legal bond between individual and state at a time, acquisition of a second nationality denoted a transfer of membership from one state to another.

4 The United States law combines renunciation of citizenship and denationalisation for birthright citizens into a category labelled expatriation. The US Constitution guarantees the citizenship of ius soli citizens as a constitutional right. The doctrine of expatriation operated on the legal fiction that certain acts by a citizen denoted an intention to renounce citizenship. In a series of judgments culminating in 1967 in Afroyim v. Rusk, the US Supreme Court progressively restricted the government's ability to deem conduct short of explicit renunciation as conclusive proof of an intention to expatriate, and the executive effectively abandoned attempts to pursue constructive expatriation in the 1980 s. 
offence and a minimum sentence of either five years or life imprisonment. The offences include treason, spying, any terrorism offence defined under the Criminal Code and a variety of offences applicable to members of the military. In the case of terrorism offences, the conviction may be by a foreign court for an offence committed outside Canada, if it would also constitute a terrorism offence under Canadian law. ${ }^{5}$ The UK law authorises citizenship stripping of naturalised citizens (but not birthright citizens) even if it renders them stateless. The Canadian law prohibits the creation of statelessness but puts the onus on the individual to satisfy the Minister that statelessness would ensue from revocation. The UK declines to publicly disclose the exact number, identities or circumstances of those deprived of UK citizenship, but investigative journalists estimate that at least 53 Britons have lost citizenship since 2002, over half on national security grounds. In 2013, the Home Secretary deprived 20 UK nationals of citizenship, more than all other years since 2002 combined. $^{6}$

Citizenship revocation raises an array of practical, legal and normative questions: Does it advance a valid objective? Does it comply with domestic, constitutional and/or transnational law? Is it normatively defensible? The answers turn, in part, on one's underlying conception of citizenship as legal status. Defenders of citizenship revocation liturgically intone that 'citizenship is a privilege, not a right'. The rhetoric of citizenship-as-privilege trades on a popular and laudable sentiment that is sometimes expressed as follows: 'I feel privileged to be a citizen of Canada, or the UK, or Italy, etc., and I consider it my duty to demonstrate my commitment through actively participating in civic life, or joining the armed forces, and standing up for my country as a good and loyal citizen should do.' But a privilege in law is something different: A privilege emanates from the patron (here a government minister) and can be rescinded from an undeserving beneficiary (here the citizen) at the former's discretion.

In two US Supreme Court cases in the 1950s, Chief Justice Warren rejected the classification of citizenship as privilege, proclaiming that 'citizenship is not a licence that expires on misbehaviour'. Instead, he invoked Hannah Arendt's

5 The law also permits revocation of a citizen who 'served as a member of an armed force of a country or as a member of an organised armed group and that country or group was engaged in an armed conflict with Canada.' This is not a criminal offence, though it is almost identical to the existing offence of treason, except that it includes non-state armed groups, whereas the offence of treason only includes armed forces of a state.

Ibid. 
famous depiction of citizenship as "no less than the right to have rights." Framing citizenship as a right vests citizenship in the rights-bearer. Depicting it as a meta-right dramatically increases the justificatory burden for any curtailment, because it places all rights in the balance.

Yet the force of Arendt's 'right to have rights' aphorism may seem attenuated, at least with respect to liberal democratic states of the twenty first century. After all, permanent residents enjoy almost all the same rights as citizens, and even foreigners without status can, in principle, claim a long menu of basic human rights under international law and many domestic legal orders. But this rejoinder overlooks one crucial fact. The exercise of virtually all rights depends on territorial presence within the state, ${ }^{8}$ and only citizens have an unqualified right to enter and remain on state territory. So once stripped of the right to enter and remain in the state, enforcement means that one is effectively deprived of all the other rights that depend (de jure or de facto) on territorial presence. This fact has not been lost on the present UK government: With two exceptions, all her targets were abroad when the Home Secretary chose to exercise her discretion to strip them of citizenship. This meant they were absent and unable to respond when the notice of intention to deprive was delivered, and therefore barred from entry qua alien in order to appeal the decision.

Another strand of citizenship discourse describes citizenship as a contract in which the citizen pledges allegiance to the sovereign in exchange for the sovereign's protection. Acts of disloyalty amount to fundamental breach of contract, and so citizenship revocation simply actualises in law the citizen's voluntary severance of the relationship. This was, more or less, the logic of constructive expatriation under US law ${ }^{9}$. But neither the rhetoric of contract nor privilege can mask the flagrantly punitive rationale for the citizenship

7 The unattributed quote comes from Arendt, H. (1951), The Origins of

Totalitarianism. New York: Harcourt \& Brace, at 294. It was picked up by US

Supreme Court Justice Warren in Perez v. Brownell, 356 US 54 (1958) at 64 and again in Trop v. Dulles, 356 U.S. 86 (1958) at 102. See discussion in Weil, P. (2013), The Sovereign Citizen. Philadelphia: University of Pennsylvania Press.

8 Expatriate voting is one exception. Many people suppose that diplomatic or consular assistance is also a right available outside the territory of the state, except that states tend to deny that they owe a legal duty to extend assistance to their citizens abroad. See, e.g. R (Abbasi) v Foreign Secretary [2002] EWCA Civ 1598.

9 The US model of expatriation implicitly relied on this metaphor to characterise a series of acts, from desertion, to voting in a foreign election, as acts signifying an intention to renounce citizenship. 
revocation regimes currently in play in the UK and Canada: baldly stated, some citizens are very bad citizens, and therefore do not deserve to be citizens. The move from 'bad citizen' to 'not citizen' is explicit in the Canadian law, where conviction for a criminal offence is a condition precedent to revocation and eventual deportation. Citizenship revocation in the UK arguably turns on prevention of future risk rather than punishment for past wrong, but statements by UK politicians like 'We think that deprivation is a way of expressing extreme displeasure at the way in which someone has behaved', reveal that the difference is more apparent than real. ${ }^{10}$

Banishment as criminal penalty has a long pedigree, and dates to a time before the rise of penal systems that enabled states to segregate, punish, rehabilitate and reintegrate wrongdoers within the state. In other words, modern states have criminal justice systems and an infrastructure that obviates the utility of banishment. These systems can, and are, deployed in response to the range of conduct encompassed under the rubric of terrorism. Banishment is both superfluous and anachronistic.

One might counter that offences threatening national security are qualitatively distinct from other offences. For these putative 'crimes against citizenship', incarceration is insufficient and withdrawal of citizenship is uniquely appropriate as supplement or substitute. It bears noting, however, that none of the Canadian offences precipitating loss of citizenship on grounds of national security - including treason - apply exclusively to citizens. Moreover, the idea that 'national security' misconduct is an affront to the state and so warrants a distinctive punishment fails to take proper account of the fact that all crime is regarded as an affront to the state's maintenance of public order (the 'King's Peace' in common law systems) and its monopoly on the legitimate use of violence. It is this public dimension of criminal law that differentiates it from private law, and confers on the state the authority to investigate, prosecute and punish wrongdoers, in addition to and apart from any private remedy that an individual victim might seek in tort, contract or property.

10 See See United Kingdom, Parliamentary Debates, HC Standing Committee E, 30 April 2002, col 54 (Angela Eagle), quoted in Thwaites, R. (2014), 'The Security of Citizenship?: Finnis in the Context of the United Kingdom's Citizenship Stripping Provisions', in F. Jenkins, M. Nolan \& K. Rubenstein (eds.), Allegiance and Identity in a Globalised World, 243-266. Cambridge, UK: Cambridge University Press, at note 94. 
The purported symmetry between 'crimes against citizenship' and denationalisation echoes the defence of the sovereign's other technique for permanent elimination of wrongdoers, namely the death penalty. Banishment fits the crime of disloyalty the way capital punishment fits the crime of murder. When tethered to expulsion, citizenship revocation effects a kind of "political death'. A citizen stripped of nationality and banished from the territory is, for all intents and purposes, dead to the state. Once outside the territory, the state has neither legal claim nor legal duty in respect of the former citizen, and is relieved of any obligation to object if another state tortures, renders or kills one of its nationals. ${ }^{11}$ Indeed, denationalisation is not only a political analogue to death, it may also be a prelude to it. ${ }^{12}$ At least two former UK citizens were executed by US drone strikes after the Home Secretary deprived them of citizenship, and another was rendered to the United States for trial on terrorism charges.

As with the death penalty, denationalisation extinguishes the prospect of rehabilitation or reintegration. The paradigmatic subject of citizenship revocation - the terrorist - is excluded from the ambit of human dignity that underwrites contemporary penal philosophy and affirms capacity for autonomy, rational self-reflection and reform. He is, in that sense, not fully human and thus incapable of rehabilitation. Banishment operates as pure and permanent retribution. There is no re-entry into the political community, no life after political death. Even creative and sophisticated attempts to classify and isolate those crimes that merit denationalisation from those that do not still founder on the instability of the distinction and the legitimacy of pure retribution. $^{13}$

11 Since the United States' lethal drone strike on US citizen Anwar al Awlaki (and his son), the United States' position is that it may lawfully execute its own citizens without trial when they are abroad. This, of course, obviates the necessity to strip citizenship prior to execution. See 'US cited controversial law in decision to kill American citizen by drone', The Guardian, 23 June 2014, available at https://www.theguardian.com/world/2014/jun/23/us-justification-drone-killing-american-citizen-awlaki. See also Spiro, P. (2014), 'Expatriating Terrorists', Fordham Law Review 82 (5): 2169-2187.

12 This was the case with the Nazi extermination of German Jewry, as Hannah Arendt recounted. First, the Nazi government stripped Jews of German nationality and then, when no country would take them in, proceeded to murder them.

13 For a recent example, see Lavi, S. (2011), 'Citizenship Revocation as Punishment: On the Modern Duties of Citizens and Their Criminal Breach', The University of Toronto Law Journal 61 (4): 783-810, at 806. 
One might object that that this parallel neglects the statelessness constraint. To the extent that a prerequisite of denationalisation is actual or potential possession of another citizenship, the individual has another political life to live somewhere else. This is also an answer to the complaint that stripping citizenship from dual nationals but not mono-nationals violates the principle of equality of citizenship. ${ }^{14}$ The dual national is not similarly situated to the mono-national precisely because the former has another citizenship and the latter does not, so differential treatment does not constitute invidious discrimination. (Of course, the counter-intuitive consequence of this reasoning is that dual citizenship becomes a liability. Multiple citizenship becomes less than the sum of its parts: the mono-citizen is secure from revocation, while the dual or multiple citizen is not).

The cogency of this argument depends on how one characterises the impact of citizenship revocation. From an external, statist perspective, the function of nationality is to catalogue the world's population and to file each person under at least one state. Nationality provides states with a return address they can stick on non-citizens for purposes of deportation, and is one reason why statelessness is an inconvenient anomaly for states. And just as all sovereign states are formally equal under international law, so too are all citizenships. Within this framework, citizenship becomes fungible. Statelessness is the problem, and nationality the solution. So, it may not actually matter what nationality a person possesses - Canadian or Somali, Brazilian or North Korean - as long as he or she possesses at least one. All nationalities are equal for purposes of averting statelessness. ${ }^{15}$ This formal equality of nationality may partly explain international law's diffidence, or at least ambiguity, on whether citizenship deprivation that does not induce statelessness may nevertheless be arbitrary and contrary to international law. ${ }^{16}$ In any event, as long as an individual retains a nationality somewhere, denationalisation poses no human rights problem.

From an internal, individual perspective, however, citizenship is not fungible. ${ }^{17}$ The revocation of citizenship severs a unique relationship between

14 It does not, of course, answer the charge of discrimination against naturalised mono-citizens under UK law. They are exposed to the risk of statelessness whereas birthright citizens are not.

15 One could even imagine how a creative government wedded to this view might venture that protecting mono-citizens from statelessness is really an affirmative action initiative under s. 15(2) of the Charter.

16 See Spiro, P. (2011), 'A New International Law of Citizenship', Am J. Int'l Law 105 (4): 694-746, at 711-12.

17 Thwaites makes a similar argument, supra note 9, at 263. 
the individual and a specific state. It is unique in two respects: First, the formal equality of nationality suppresses the substantive inequality of citizenship. The bundle of social, political, economic, cultural and legal opportunities and entitlements to which citizenship provides access varies radically between countries. Canadian or Brazilian citizenship is dramatically and indisputably heftier than that of present-day North Korea or Somalia.

Secondly, the subjective experience of that legal bond, what the International Court of Justice in Nottebohm v. Guatemala calls 'the social fact of attachment ${ }^{18}$ is as infinitely diverse as the people who make up the citizenry. It may range from the 'nominal citizen' whose social attachment is highly attenuated, to the individual whose existence is, and has always been, wholly and exclusively embedded in the country of residence. Citizenships are not substantively equal in comparison to one another and the nature of the individual citizen-state relationship is not invariant. But my point is not to propose a metric capable of measuring the quantitative, qualitative, experiential, emotional, personal, familial, cultural, social, financial, linguistic and political impacts of exile on any individual, in order that some state official could determine precisely when citizenship revocation inflicts an appropriate versus excessive degree of punishment. Citizenship as legal status obviates both the need and the legitimacy of an on-going or comparative evaluation by state authorities of how much or how well a citizen performs as a citizen. ${ }^{19}$ The very act of subjecting a subsisting citizenship to this kind of normative scrutiny subverts the security that distinguishes legal citizenship from other statuses that define the relationship between state and individual.

The history of banishment generates only cautionary tales about the inevitably arbitrary and prejudicial abuse of a discretionary power to identify the 'bad' citizen for purposes of relegating him or her to the non-status of non-citizen. The violence of rupturing the link between citizens and state is not negated by possession of citizenship status in another polity, if one conceives of the relationship (whatever its intensity, depth, etc.) between a state and a citizen as singular and unique. On this view, citizenship revoca-

18 Nottebohm (Liechtenstein v. Guatemala), ICJ 4 (1955) at 23.

19 This does not preclude an argument that the depth and duration of a resident non-citizen's relationship to a state could and should generate an entitlement to remain and to be put on a path to citizenship. See, e.g. Carens, J. (2013), The Ethics of Immigration. Oxford: OUP. 
tion inflicts an intrinsically grave harm that is separate from (though exacerbated by) the harm of statelessness. ${ }^{20}$

I leave to one side an account of the myriad procedural and substantive deficiencies of the UK and Canadian denationalisation regimes that make them ripe for legal challenge. Nor do I dwell here on the dubious practical value of denationalisation in preventing terrorism or protecting national security. Suffice to say that if the aim of citizenship revocation is deterrence, there is no evidence that stripping citizenship will deter a potential terrorist any more or better than the prospect of a criminal conviction and lengthy imprisonment or, for that matter, the risk of blowing oneself up, getting killed or executed, or being detained indefinitely, rendered, or tortured. To the extent that exile supposedly makes a country more secure by removing dangerous people, the justification knows no limits: it is not obvious why Canadians or Britons would not also be made safer by exiling all citizens who commit violent offences. From the other side, expelling convicted or alleged terrorists is an oddly parochial response that transfers rather than reduces risk. Depending on the destination country, deportation may actually make it easier for the individual to engage in activities that pose a threat to global security. ${ }^{21}$

And, finally, the sheer absurdity of banishment as a response to the terrorist qua global outlaw is best illustrated by speculating on what would happen if all states behaved like the UK and Canada: Imagine a dual UK-Canada citizen who is convicted of a terrorism offence in the UK. Since terrorism is a global menace, Canada can treat a terrorism conviction in the UK as proof of being a bad Canadian citizen. Both Canada and the UK can lawfully denationalise him. But both states are also somewhat constrained in law not to create statelessness, and both want and need to find another state to admit the expelled person. And the only country that has a legal obligation to do is a state of nationality. So, now it becomes a race between Canada and the UK to see which country can strip citizenship first. To the loser goes the citizen.

Modern exile, as imagined under UK and Canadian law, is erected upon unsustainable and incoherent propositions about the nature of legal citizenship. If citizenship is irrevocable only where withdrawal causes statelessness, then citizenship is a right for mono-citizens but a privilege for dual or

20 For a similar argument, see Rayner Thwaites, supra note 9.

21 Macklin, A. (2001), 'Borderline Security', in R. Daniels et al. (eds.), The

Security of Freedom: Essays on Canada's Anti-Terrorism Bill, 383-405.

Toronto: U of T Press; 'Still Stuck at the Border', in C. Forcese \& F. Crépeau (eds.), Terrorism, Law and Democracy: 10 Years After 9/11, 261-306.

Montreal: Canadian Institute for the Administration of Justice. 
multiple citizens. Legal citizenship can be contingent on normative criteria for one state if and only if it is not similarly contingent for another state. State A can deprive a national of citizenship and banish him because he is a bad citizen. But State A can do so lawfully if and only if State B is compelled to admit the individual simply because he is a citizen of State B, irrespective of whether he is a good or bad citizen of State B. One state's authority to deem the bad citizen a non-citizen presupposes another state lacking that same authority.

To contend that punitive denationalisation in the twenty-first century is an illegitimate and futile exercise of sovereign power does not refute or deny that social solidarity, belonging and allegiance have a place in conceptions of citizenship and deserve to be promoted. It is rather that these goals will not and cannot be advanced by citizenship revocation. Nor will citizenship revocation make any state, or the global community, more secure. Citizenship revocation only enhances the discretionary and arbitrary power of the executive, at the expense of all citizens, and of citizenship itself. Banishment deserves to be banished again. Permanently.

Open Access This chapter is licensed under the terms of the Creative Commons Attribution 4.0 International License (http://creativecommons.org/licenses/by/4.0/), which permits use, sharing, adaptation, distribution and reproduction in any medium or format, as long as you give appropriate credit to the original author(s) and the source, provide a link to the Creative Commons license and indicate if changes were made.

The images or other third party material in this chapter are included in the chapter's Creative Commons license, unless indicated otherwise in a credit line to the material. If material is not included in the chapter's Creative Commons license and your intended use is not permitted by statutory regulation or exceeds the permitted use, you will need to obtain permission directly from the copyright holder.

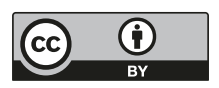

